\title{
Intensified Microwave-Assisted N-Acylation Procedure - Synthesis and Activity Evaluation of TRPC3 Channel Agonists with a 1,3-Di- hydro-2H-benzo[d]imidazol-2-one Core
}

\author{
Gema Guedes de la Cruz ${ }^{\mathrm{a}}$ \\ Barbora Svobodovab \\ Michaela Lichtenegger ${ }^{b}$ \\ Oleksandra Tiapko ${ }^{b}$ \\ Klaus Groschner*b \\ Toma Glasnov*a \\ anstitute of Chemistry, University of Graz and NAWI Graz, \\ Heinrichstrasse 28, 8010 Graz, Austria \\ toma.glasnov@uni-graz.at \\ b Institute of Biophysics, Medical University of Graz, \\ Harrachgasse 21/IV, 8010 Graz, Austria \\ klaus.groschner@medunigraz.at
}
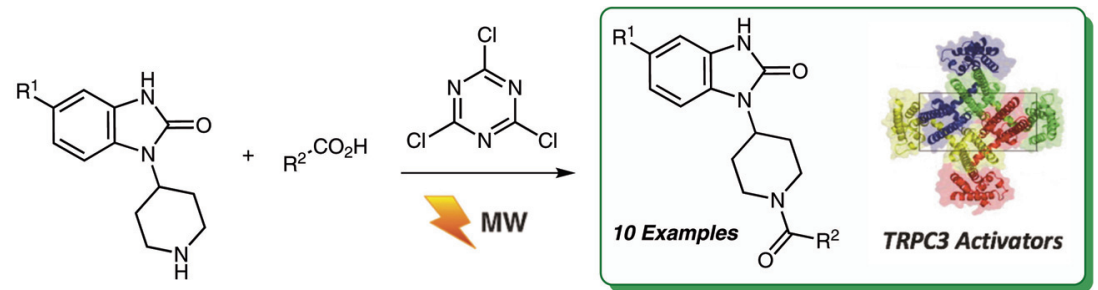

Received: 23.09.2016

Accepted after revision: 14.11.2016

Published online: 08.12 .2016

DOI: 10.1055/s-0036-1589472; Art ID: st-2016-b0634-I

License terms: (C) (P)

Abstract Upon controlled microwave heating and using cyanuric chloride as a coupling reagent, an efficient amidation procedure for the synthesis of 1,3-dihydro-2H-benzo[d]imidazol-2-one-based agonists of TRPC3/6 ion channels has been developed. Compared to the few conventional protocols, a drastic reduction in processing time from ca. 2 days down to 10 minutes was achieved accompanied by significantly improved product yields. The robustness of the method was confirmed by 18 additional examples including aromatic, aliphatic, and heterocyclic amines and acids. The obtained agonists were screened for biological activity at $1 \mu \mathrm{M}$ concentration and few structure-activity relations have been established.

Key words microwave synthesis, acylation, amides, $\mathrm{Ca}^{2+}$-signaling, TRPC ion channels, agonist

The cation canonical transient receptor potential channels (TRPC3/6) are mechanosensitive, receptor- and storeoperated channels that mediate $\mathrm{Ca}^{2+} / \mathrm{Na}^{+}$influx into cells to govern cellular functions in response to stimulation of phospholipase C-coupled membrane receptors. The TRPC3/6 channels are implicated in several human pathologies - focal segmental glomerulosclerosis, pulmonary hypertension, ischaemia reperfusion-induced lung oedema, myocardial hypertrophy, as well as in the regulation of vascular tone, cell growth, proliferation, and inflammation. ${ }^{1}$ Thus, since the discovery of the TRPC-channel subtypes in the 1990s, potent and selective small-molecule TRPC3/6 agonist and antagonist tools are being sought to study the functions of these lipid-sensitive channels and to evaluate the therapeutic potential of such pharmacological modulators. ${ }^{2}$ Recently, a small 1,3-dihydro-2H-benzo[d]imidazol2-one-based potent agonist (GSK1702934A, Figure 1) has been briefly described by a team at GlaxoSmithKline-US as a tool to activate lipid-sensitive TRPC channels directly, bypassing phospholipase-C signaling. ${ }^{3}$

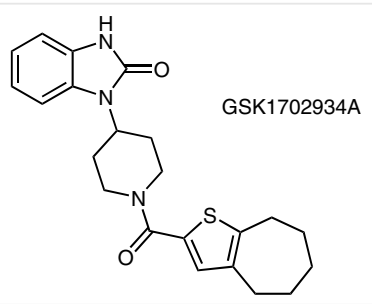

Figure 1 GSK1702934A - a potent TRPC3/6-channel agonist

Whole-cell patch-clamp experiments demonstrated that GSK1702934A is able to induce TRPC3/6-currents in HEK293 cells transduced with recombinant human TRPC3/6 with an $\mathrm{EC}_{50}$ of ca. $0.08 \mathrm{mM}$ and $0.44 \mathrm{mM}$, respectively. In a continuation of our attempts to evaluate the potential value of TRPC $3 / 6$ channels as direct pharmacological targets, we sought for the enhanced synthesis of novel 1,3dihydro-2H-benzo[d]imidazol-2-one-based synthetic activators in an intensified process from commercially available starting materials.

Herein we disclose an improved, single-step synthetic protocol that provides a direct access to novel agonists of TRPC $3 / 6$ channels by the means of microwave heating and cyanuric chloride as an effective coupling reagent. Moreover, the agonist effects of novel synthetic TRPC3 activators, generated by the means of the enhanced synthetic protocol, were examined and few essential structure-activity relationships were established.

For the envisaged synthesis, an optimized N-acylation protocol was needed. Previously, we gained access to small amounts of GSK1702934A by the means of a traditional amide-bond-generation method using commercially avail- 
able starting materials in a two-step procedure (Scheme 1) and for the purpose of uncovering (patho)physiological functions of the TRPC $3 / 6$ channels. ${ }^{4}$ Thus, an acid chloride of a corresponding acid was generated and used in a following coupling step. Moreover, an earlier microwave N-acylation procedure ${ }^{5}$ successful in the synthesis of pyrazolebased selective inhibitors of TRPC $3 / 6$ channels provided lower yields from a complex reaction mixture (data not shown).

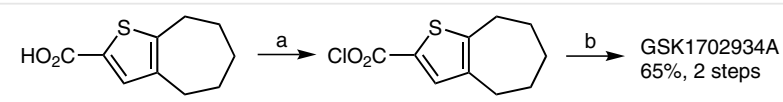

Scheme 1 Previous synthesis of GSK1702934A. Reagents and conditions: a) oxalyl chloride, DMF, $\mathrm{CH}_{2} \mathrm{Cl}_{2}, 0{ }^{\circ} \mathrm{C}$ to r.t., $1 \mathrm{~h}, 80 \%$; b) 4-(2-keto-1-benzimidazolinyl)piperidine, DMAP, $\mathrm{CH}_{2} \mathrm{Cl}_{2}, 0{ }^{\circ} \mathrm{C}$ to r.t., $15 \mathrm{~min}, 82 \%$.

At this stage, with the available preliminary data at hand, and excluding further standard room-temperature coupling reagents such as PyBOP/DIPEA (that typically require rather long reaction times and are relatively expensive), we turned our attention to a recent literature report by Rad et al. that describes an experimentally very straightforward amidation process towards $\mathrm{N}$-acylated nucleobases. ${ }^{6}$ The described procedure involves simple heating of diverse nucleobases and carboxylic acids (aromatic, aliphatic, heterocyclic) at $110{ }^{\circ} \mathrm{C}$ using cyanuric chloride in the presence of $\mathrm{NaH}$ and $\mathrm{Et}_{3} \mathrm{~N}$ in DMF-MeCN (1:1) as a solvent mixture. Cyanuric chloride (2,4,6-trichloro-1,3,5-triazine, TCT), besides other synthetic applications, is also a suitable activating reagent for the in situ generation of acid halides that is a frequently used technique in peptide synthesis. ${ }^{7}$ It is a safe, cost-effective, and stable reagent that is amenable to large-scale production. ${ }^{7 \mathrm{a}, \mathrm{i}}$ While working at elevated temperatures and with good yields, the reported reaction needed at least six and up to 18 hours for some substrates to reach completion. For these reasons, we sought for the intensification of the process by applying microwave heating while at the same time looking for a milder base to work with. It was easy to foresee that the application of microwave heating could potentially enhance the process. ${ }^{8}$

In our optimization efforts we used 4-(2-keto-1-benzimidazolinyl)piperidine (Table $1, \mathbf{A}$ ) and octanoic acid (Table $1, \mathbf{B})$ as reaction partners, envisaging our attempts to prepare TRPC3 agonists. In few preliminary experiments (data not shown for simplicity), pyridine could be selected as the sole organic base of choice to replace the $\mathrm{NaH}-\mathrm{Et}_{3} \mathrm{~N}$ combination and $\mathrm{MeCN}$ as the preferred solvent. To access the optimal reaction conditions, we elaborated the best reagent ratio and the reaction temperature with a reaction time limit set at 5 minutes (Table 1).

An exploratory room-temperature trial was terminated after six days, resulting in only $22 \%$ conversion, as determined by HPLC. In a further experiment, we could confirm the mechanistic necessity to use pyridine as a base (Table 1, entry 1). ${ }^{9}$ As expected, the obtained result clearly demonstrated the crucial role of pyridine since only trace amounts of amide 1a were detected in the reaction mixture. Fine tuning of the reaction temperature and the reagent stoichiometry ultimately led to the final synthetic protocol (Table 1 , entry $6 ; 1.2$ equiv of amine, 1 equiv of acid, 0.6 equiv of TCT, and 1.5 equiv of pyridine) providing full conversion and highest selectivity for the desired amide. ${ }^{10}$ Isolation of

Table 1 Optimization of the TCT-Promoted Microwave N-Acylation

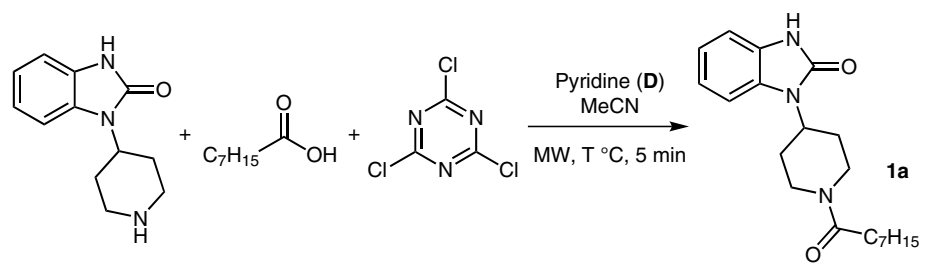

Amine (A) Octanoic acid (B) TCT (C)

\begin{tabular}{|c|c|c|c|}
\hline Entry & $\mathbf{A} / \mathbf{B} / \mathbf{C} / \mathbf{D}$ (equiv) & Temp $\left({ }^{\circ} \mathrm{C}\right)$ & Conv. $(\%)^{\mathrm{a}}$ \\
\hline $1^{\mathrm{b}}$ & $1.0 / 1.2 / 0.42$ & 90 & traces \\
\hline 2 & $1.0 / 1.2 / 0.42 / 1.5$ & 90 & 52 \\
\hline 3 & $1.0 / 1.2 / 0.42 / 1.5$ & 120 & 68 \\
\hline 4 & $1.0 / 1.2 / 0.42 / 1.5$ & 140 & $93(54)^{c}$ \\
\hline $5^{d}$ & $1.0 / 1.2 / 0.42$ & 140 & 22 \\
\hline 6 & $1.2 / 1.0 / 0.6 / 1.5$ & 140 & $100(63),{ }^{c}(47)^{e}$ \\
\hline
\end{tabular}

a Determined by HPLC at $215 \mathrm{~nm}$.

b Pyridine as a base was omitted.

c Isolated yield after flash chromatography given in parentheses.

d Pyridine used as a solvent.

e Isolated yield from a comparable microwave protocol using $\mathrm{PCl}_{3}$ for the in situ generation of an acid chloride instead of TCT. ${ }^{5}$ 
the amide 1a by flash chromatography furnished 63\% product yield, a significant improvement to the $47 \%$ obtained in a $\mathrm{PCl}_{3}$-mediated microwave procedure. Additionally, we wondered how robust the optimized protocol was, and conducted an extended study with a set of various commercial amines and acids (Table 2). Gratifyingly and in all of the evaluated 20 examples, we could access the expected amides via the tolerant microwave protocol and after a simple and direct chromatography workup (for details see the Supporting Information). Interestingly, all tested examples with heterocyclic amines or acids provided better yields as compared to a $\mathrm{PCl}_{3}$-mediated microwave procedure (Figure 2). Examples of primary, secondary, heteroaromatic, and heterocyclic amines and acids were successfully investigated as well (Table 1 and Figure 2).

Table 2 Confined Scope of the TCT-Promoted Microwave N-Acylation

\begin{tabular}{lllll}
\hline Entry & Amine & Acid & Amide & Yield (\%)
\end{tabular}<smiles>Nc1ccc([N+](=O)[O-])cc1</smiles><smiles>O=C(O)c1ccccc1</smiles>

2<smiles>Nc1ccc(F)cc1</smiles>

3<smiles>Cc1cc(N)cc(C)c1C</smiles>

4<smiles>CNc1ccc([N+](=O)[O-])cc1</smiles>

5<smiles>CNc1ccc(F)cc1</smiles>

6<smiles>CNc1ccccc1C(F)(F)F</smiles><smiles>c1ccc2c(c1)CCN2</smiles><smiles>O=C(O)c1ccccc1</smiles><smiles>O=C(O)c1ccccc1</smiles><smiles>O=C(O)c1ccccc1</smiles><smiles>O=C(O)c1ccccc1</smiles><smiles>O=C(O)c1ccccc1</smiles><smiles>O=C(O)c1ccccc1</smiles><smiles>O=C(O)c1ccccc1</smiles><smiles>O=C(O)c1ccccc1</smiles><smiles>O=C(Nc1ccc([N+](=O)[O-])cc1)c1ccccc1</smiles><smiles>O=C(Nc1ccc(F)cc1)c1ccccc1</smiles><smiles>Cc1cc(NC(=O)c2ccccc2)cc(C)c1C</smiles><smiles>CN(C(=O)c1ccccc1)c1ccc([N+](=O)[O-])cc1</smiles><smiles>CN(C(=O)c1ccccc1)c1ccc(F)cc1</smiles><smiles>CN(C(=O)c1ccccc1)c1ccccc1C(F)(F)F</smiles><smiles>O=C(c1ccccc1)N1CCc2ccccc21</smiles><smiles>O=C(c1ccccc1)N1CCCc2ccccc21</smiles><smiles>O=C(c1ccccc1)N1c2ccccc2Oc2ccccc21</smiles> 
Table 2 (continued)

\begin{tabular}{|c|c|c|c|c|}
\hline Entry & Amine & Acid & Amide $^{a}$ & Yield (\%) \\
\hline 10 & & & & 45 \\
\hline 11 & & & & 82 \\
\hline 12 & & & & 74 \\
\hline 13 & & & & 76 \\
\hline 14 & & & & 86 \\
\hline 15 & & & & 74 \\
\hline 16 & & & & 59 \\
\hline 17 & & & & 87 \\
\hline 18 & & & & 82 \\
\hline 19 & & & & 79 \\
\hline 20 & & & & 39 \\
\hline
\end{tabular}

${ }^{a}$ Isolated yield after flash chromatography. 
Finally, we focused our attention on the synthesis of few selected 1,3-dihydro-2H-benzo[d]imidazol-2-one based amides (Figure 2). The newly synthesized compounds were easily obtained in up to $85 \%$ yields and fully characterized by means of ${ }^{1} \mathrm{H}$ NMR, ${ }^{13} \mathrm{C}$ NMR, and high-resolution MS (APCI). Corresponding amounts were submitted to a semipreparative HPLC purification after initial flash chromatography to assure highest purity ( $>99 \%$ ) prior the evaluation of the pharmacological effect on TRPC3 channels.
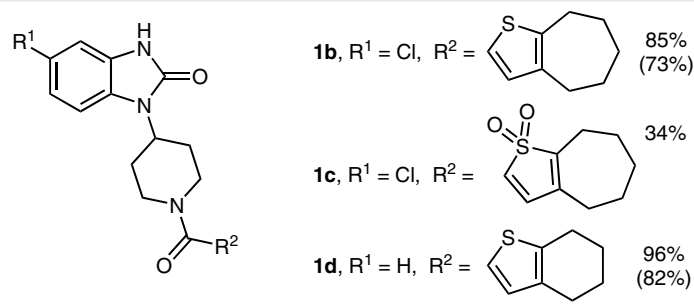

$$
\begin{aligned}
& \text { 1e, } R^{1}=H, R^{2}=\|^{S} \begin{array}{c}
85 \% \\
(58 \%)
\end{array} \quad \text { 1f, } R^{1}=C l, R^{2}=\text { as } 1 \text { e } \begin{array}{c}
89 \% \\
(50 \%)
\end{array} \\
& 1 \mathrm{~g}, \mathrm{R}^{1}=\mathrm{H}, \mathrm{R}^{2}=
\end{aligned}
$$

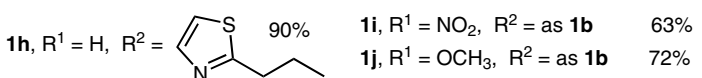

Figure 2 Library of selected 1,3-dihydro-2H-benzo[d]imidazol-2-onebased amides. Isolated yields from a comparable microwave protocol using $\mathrm{PCl}_{3}$ for the in situ generation of an acid chloride instead of $\mathrm{TCT}^{5}$ are shown in parentheses.

To assess the activity of the synthesized GSK1702934Aanalogues $\mathbf{1 a}-\mathbf{j}$ in terms of TRPC channel activation, voltage-clamp technique in whole-cell mode on TRPC3-overexpressing HEK293 cells was employed. The compound-induced current densities at positive and negative test potentials were compared (Figure 3). Patch clamp recordings were initiated in extracellular solution (ECS) free of activators followed by continuous perfusion with ECS containing the test compound of interest at $1 \mu \mathrm{M}$ concentration (see the Supporting Information for full experimental details). Satisfyingly, application of the various structural analogues of GSK1702934A provoked a TRPC3 current, whereby the response to amides $\mathbf{1 c}, \mathbf{1 e}$, and $\mathbf{1 i}$ was almost negligible (Figure 3). Interestingly, the outward current at $70 \mathrm{mV}$ was comparable with the original TRPC3-agonist for all other tested amides (1a,b,f,h). Furthermore, inward currents at $-90 \mathrm{mV}$ were slightly smaller or similar to those observed with GSK1702934A. Inspection of current-to-voltage relations indicated no significant difference in selectivity of the conductance generated by the different compounds (data not shown). Importantly, the aliphatic ring adjacent to the thiophene core appears crucial for the observed agonist properties. Reducing the ring size does not significantly alter the activity profile. At the same time, oxidation of the sulfur is detrimental (Figure 3, 1c). The results obtained with compound 1e could be interpreted by low solubility in the standard solution used for the patch clamp experiments (see the Supporting Information). Introducing substituents $\left(\mathrm{Cl}, \mathrm{OCH}_{3}, \mathrm{NO}_{2}\right)$ on the benzoimidazole ring decreases the observed activity $\left(\mathrm{H}>\mathrm{Cl}>\mathrm{OCH}_{3}>\mathrm{NO}_{2}\right)$. Installing a thiazole ring with adjacent short aliphatic chain provided a compound $(\mathbf{1 h})$ with identical activity to the originally reported GSK1702934A.

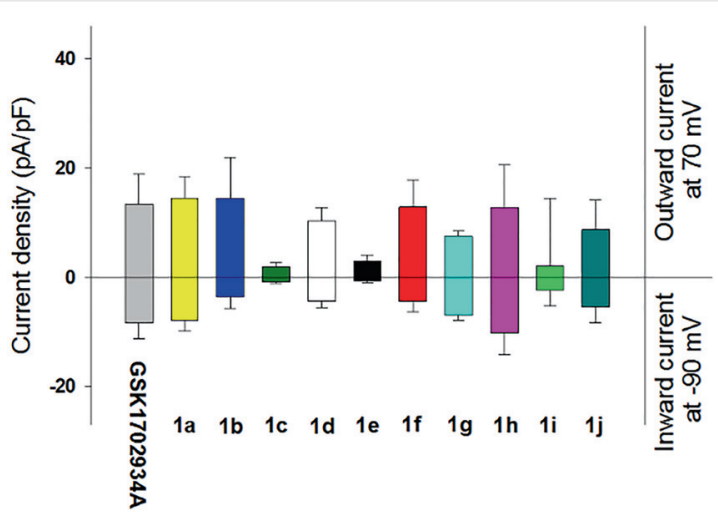

Figure 3 Screening of GSK1702934A analogues 1a-j: Comparison of current densities at $-90 / 70 \mathrm{mV}$ ( $\mathrm{n} \geq 5$ for each condition) induced by the individual amides at $1 \mu \mathrm{M}$ concentration in TRPC3-overexpressing HEK293 cells. Mean values \pm SEM are depicted.

In conclusion, we present an intensified synthetic protocol for the generation of various amides, including selected examples of 1,3-dihydro- $2 \mathrm{H}$-benzo[d]imidazol-2-ones with promising agonist activity on mammalian TRPC3 channels. Our method relies on the use of automated highspeed microwave synthesis and benefits from the use of low-cost commercial cyanuric chloride as an effective coupling reagent in a single-step protocol. Therefore, we believe that the reduction of reaction and overall processing time and the higher yields as compared to other methods make our procedure amenable for the rapid generation of related compound libraries on the search for agonist-activity enhancement building on the collected structure-activity relationship data. Finally, we could find a new and structurally simpler motif that provides identical activation of TRPC3 channels as compared to GSK1702934A. Thus, the presented results could lead to further improvement of the available tools to deepen the functional studies of these lipid-sensitive channels.

\section{Acknowledgment}

This work was supported by a grant (P28243-B27) from the Austrian Science Funds (FWF). We thank to Mrs. Chiara Mayer for her help. 


\section{Supporting Information}

Supporting information for this article is available online at http://dx.doi.org/10.1055/s-0036-1589472.

\section{References and Notes}

(1) (a) Lichtenegger, M. In Mammalian Transient Receptor Potential (TRP) Cation Channels, Vol. 1; Nilius, B.; Flockerzi, V., Eds.; Springer: Berlin/Heidelberg, 2014, 67-84. (b) Dietrich, A. In Mammalian Transient Receptor Potential (TRP) Cation Channels, Vol. 1; Nilius, B.; Flockerzi, V., Eds.; Springer: Berlin/Heidelberg, 2014, 157-188. (c) Pathologies of Calcium Channels; Weiss, N.; Koschak, A., Eds.; Springer: Berlin/Heidelberg, 2014.

(2) (a) Harteneck, C.; Gollasch, M. Curr. Pharm. Biotechnol. 2011, 12, 35. (b) Bon, R. S.; Beech, D. J. Br. J. Pharmacol. 2013, 170, 459. (c) Gautier, M.; Dhennin-Duthille, I.; Ay, A. S.; Rybarczyk, P.; Korichneva, I.; Ouadid-Ahidouch, H. Br. J. Pharmacol. 2014, 171, 2582.

(3) Xu, X.; Lozinskaya, I.; Costell, M.; Lin, Z.; Ball, J. A.; Bernard, R.; Behm, D. J.; Marion, J. P.; Schnackenberg, C. G. Biophys. J. 2013, 104, 454a; Suppl. 1.

(4) Doleschal, B.; Primessnig, U.; Wölkart, G.; Wolf, S.; Schernthaner, M.; Lichtenegger, M.; Glasnov, T.; Kappe, C. O.; Mayer, B.; Antoons, G.; Heinzel, F.; Poteser, M.; Groschner, K. Cardiovasc. Res. 2015, 106, 163.

(5) (a) Colombo, M.; Bossolo, S.; Aramini, A. J. Comb. Chem. 2009, 11, 335. (b) Glasnov, T. N.; Groschner, K.; Kappe, C. O. ChemMedChem 2009, 4, 1816.

(6) Rad, M. N. S.; Behrouz, S.; Arari, Z.; Khalafi-Nezhad, A. Monatsh. Chem. 2014, 145, 1933.

(7) Selected references: (a) Rayle, H. L.; Fellmeth, L. Org. Process Res. Dev. 1999, 3, 172. (b) Montalbetti, C. A. G. N.; Falque, V. Tetrahedron 2005, 61, 10827. (c) Blotny, G. Tetrahedron 2006, 62, 9507. (d) Bergman, K.; Elvingson, C.; Hilborn, J.; Svensk, G.; Bowden, T. Biomacromolecules 2007, 8, 2190. (e) Chen, C.-Y.; Frey, L. F.; Shultz, S.; Wallace, D. J.; Marcantonio, K.; Payack, J. F.; Vazquez, E.; Springfield, S. A.; Zhou, G.; Liu, P.; Kieczykowski, G. R.; Chen, A. M.; Phenix, B. D.; Singh, U.; Strine, J.; Izzo, B.; Krska, S. W. Org. Process Res. Dev. 2007, 11, 616. (f) Prasad, K. V. S. R. G.; Bharthi, K.; Haseena, B. B. Int. J. Pharm. Sci. Rev. Res. 2011, 8, 108. (g) ElFaham, A.; Albericio, F. Chem. Rev. 2011, 111, 6557. (h) Duangkamol, C.; Jaita, S.; Wangnagae, S.; Phakhodee, W.;
Pattarawarapan, M. RSC Adv. 2015, 5, 52624. (i) Dunetz, J. R.; Magano, J.; Weisenburger, G. A. Org. Process Res. Dev. 2016, 20, 140.

(8) Selected references: (a) Alterman, M.; Andersson, H. O.; Garg, N.; Ahlsén, G.; Lövgren, S. B.; Classon, B.; Danielson, U. H.; Kvarnström, I.; Vrang, L.; Unge, T.; Samuelsson, B. A.; Hallberg, A. J. Med. Chem. 1999, 42, 3835. (b) Varma, R. S. Green. Chem. 1999, 1, 43. (c) Nöteberg, D.; Schaal, W.; Hamelink, E.; Vrang, L.; Larhed, M. J. Comb. Chem. 2003, 5, 456. (d) Microwaves in Organic Synthesis, 3rd ed., Vol. 1; de la Hoz, A.; Loupy, A., Eds.; Wiley-VCH: Weinheim, 2012. (e) Microwaves in Organic Synthesis, 3rd ed., Vol. 2; de la Hoz, A.; Loupy, A., Eds.; Wiley-VCH: Weinheim, 2012.

(9) Schnyder, A.; Beller, M.; Mehltretter, G.; Nsenda, T.; Studer, M.; Indolese, A. F. J. Org. Chem. 2001, 66, 4311.

(10) General Experimental Procedure for Microwave-Assisted TCT-Acylation

To a stirred mixture of a corresponding acid $(0.819 \mathrm{mmol}, 1$ equiv), cyanuric chloride ( $90.5 \mathrm{mg}, 0.491 \mathrm{mmol}, 0.6$ equiv), dry pyridine (99.1 mg, $1.23 \mathrm{mmol}, 1.5$ equiv), and dry $\mathrm{MeCN}$ (4.5 $\mathrm{mL}$ ) in a $5 \mathrm{~mL}$ Pyrex microwave vial, equipped with a magnetic stir bar, the corresponding amine $(0.983 \mathrm{mmol}, 1.2$ equiv) was added after initial stirring at r.t. for $5 \mathrm{~min}$. The reaction mixture was then crimped with a Teflon septum, stirred for $10 \mathrm{~s}$, and subjected to microwave heating for $5 \mathrm{~min}$ (fixed hold time) at $140{ }^{\circ} \mathrm{C}$ and subsequently cooled down to $40{ }^{\circ} \mathrm{C}$. The resulting reaction mixture was concentrated under reduced pressure, and the residue was purified by flash chromatography (with $\mathrm{CHCl}_{3}$ or a gradient of $0-10 \% \mathrm{MeOH}$ in $\mathrm{CHCl}_{3}$ ) to afford amides $\mathbf{1 a - g}$. For pharmacological experiments, analytical-grade samples of compounds 1a-g were additionally purified by the means of a semipreparative HPLC (see the provided Supporting Information).

1-(1-Octanoylpiperidin-4-yl)-1,3-dihydro-2H-benzo[d]imidazol-2-one (1a)

Transparent oil; yield $177 \mathrm{mg}(63 \%) .{ }^{1} \mathrm{H}$ NMR $\left(300 \mathrm{MHz}, \mathrm{CDCl}_{3}\right)$ : $\delta=10.05(\mathrm{br} \mathrm{s}, 1 \mathrm{H}), 7.15-7.04(\mathrm{~m}, 4 \mathrm{H}), 4.90(\mathrm{~d}, J=13.1 \mathrm{~Hz}, 1 \mathrm{H})$, 4.60-4.52 (m, $1 \mathrm{H}), 4.07(\mathrm{~d}, J=13.1 \mathrm{~Hz}, 1 \mathrm{H}), 3.20(\mathrm{t}, J=12.9 \mathrm{~Hz}$, $1 \mathrm{H}), 2.68(\mathrm{t}, J=13.5 \mathrm{~Hz}, 1 \mathrm{H}), 2.43-2.26(\mathrm{~m}, 4 \mathrm{H}), 1.93-1.88(\mathrm{~m}$, $2 \mathrm{H}), 1.73-1.64(\mathrm{~m}, 2 \mathrm{H}), 1.40-1.25(\mathrm{~m}, 8 \mathrm{H}), 0.88(\mathrm{t}, J=6.8 \mathrm{~Hz}, 3$ H). ${ }^{13} \mathrm{C}$ NMR $\left(75 \mathrm{MHz}, \mathrm{CDCl}_{3}\right): \delta=171.9,155.1,129.0,128.2$, 121.6, 121.3, 110.1, 109.4, 50.9, 45.4, 41.5, 33.6, 31.9, 29.6, 29.3, 25.6, 22.8, 14.2. HRMS (APCI): $\mathrm{m} / z$ calcd for $\mathrm{C}_{20} \mathrm{H}_{30} \mathrm{~N}_{3} \mathrm{O}_{2}[\mathrm{M}+$ $\mathrm{H}^{+}:$344.2332; found: 344.2334 . 